\title{
В.В. Никитин
}

\section{ВОЗНИКНОВЕНИЕ СОВЕТСКОЙ ЗАДОЛЖЕННОСТИ И ПУТИ ЕЕ УРЕГУЛИРОВАНИЯ В СЛОВАЦКО-РОССИЙСКИХ ОТНОШЕНИЯХ В 1990-х гГ.}

\begin{abstract}
Впервые в историографии на основе архивных материалов обстоятельно рассказывается о причинах возникновения советских и российских долговых обязательств перед Чехословакией в 1989-1992 гг. Особо анализируются основные направления их погашения, которые обсуждались в 1993-1998 гг. в ходе словацко-российских переговоров на разных уровнях. Описаны основные механизмы урегулирования задолженности, показана динамика переговоров и рассмотрена словацко-российская договорно-правовая база по данному вопросу.

Ключевые слова: погашение советской задолженности; словацко-российские отношения; внешняя политика; экономические отношения; дипломатия.
\end{abstract}

Проблема возникновения задолженности бывшего СССР перед странами Центральной и Юго-Восточной Европы привлекала и привлекает внимание многих исследователей как в 1990-х гг., так и в настоящее время. Словацкие журналисты, публицисты и политологи заняли еще в 1990-е гг. антирусскую позицию, пытаясь доказать чуть ли не предательство словацких национальных интересов правительством Владимира Мечьяра. Поэтому на первый план выдвигались поставки военной техники в счет погашения российской задолженности перед Словакией и, таким образом, создавалось впечатление об исключительной ориентации Словакии на Россию. При этом другие формы снижения Россией долговых обязательств перед Словакией в расчет ими не принимались. Словацкий политолог А. Дулеба не смог даже объяснить причины возникновения советского долга [1. S. 215-228; 2. S. 19-35; 3. S. 38-55]. И это несмотря на то, что еще в начале 1995 г. словацкий экономист А. Дмитренко в газете «Народна оброда» объяснял как природу возникновения задолженности, так и пути ее урегулирования [4. S. 8].

Российские же историки подошли к этому вопросу с диаметрально противоположных позиций. Указывалось, в частности, что проблема урегулирования задолженности привела к погашению интереса России «к развитию торговых отношений со странами, отказавшимися идти на списание и иные уступки в этом процессе» [5. С. 252-253, 261]. К сожалению, с такой трактовкой сегодня уже невозможно согласиться. Однако особенно необходимо подчеркнуть тот факт, что по объективным причинам они не имели возможности работать с серьезными источниками. Доступность словацких архивных документов в настоящее время дает возможность весьма качественно и подробно проанализировать это важнейшее направление словацкороссийских отношений в 1990-х гг.

Основу чехословацко-советских экономических отношений в течение сорокалетней истории составлял бартер. Сегодня рыночные экономисты характеризуют его как «особый вид торговых операций», насчитывав- ший к концу XX в., по разным оценкам, от 8 до 20\% от мировой торговли [6. S. 314-315; 7. S. 566-567]. Бартер - это тип торговли, в которой товар одного участника торговой сделки обменивается на товар второго. В то время такой экономический механизм осуществлялся многими странами, причем их количество росло: если в 1970-х гг. бартерные операции проводились приблизительно 10 государствами, то в середине 1990-х гг. в них участвовали уже более 100 стран [6. S. 315].

В чехословацко-советских отношениях, по сути дела, это была корзина поставляемого из СССР в ЧССР производства, которая соответствовала по цене набору чехословацких товаров, экспортируемых в Советский Союз. Таким образом, в этой внешнеторговой схеме экспортируемое изделие оплачивалось не финансовыми средствами, а другим видом производства. Как констатировалось в одном словацком правительственном материале, такая «методика организации торговых отношений» в рамках стран Совета экономической взаимопомощи (СЭВ) «обеспечивала бездефицитный ежегодный торговый баланс между отдельными странами» [8. S. 1].

Но это было не единственное преимущество данного механизма. Обращает на себя внимание и тот факт, что на такую торговлю не мог повлиять никакой финансовый кризис, и, наоборот, финансовый кризис не мешал развитию внешнеторговых операций.

При всех этих «плюсах», существовали, однако, и отрицательные стороны бартерных операций. Так, например, в связи с созданием в середине 1990 г. валютного, экономического и социального союза между ГДР и ФРГ, Восточная Германия в одностороннем порядке отменила контракты, заключенные еще 1989 г. на поставку чехословацких товаров [9. S. 3]. К тому же, в июле 1990 г. ГДР назначила внутренний курс обмена переводного рубля к немецкой марке 1 к 2,3, что привело к неконкурентоспособности чехословацких товаров на восточно-немецком рынке. В итоге возник долг Чехословакии на уровне более 600 млн руб. (почти 5 млрд чехословацких крон), а потеря чехословацкой экономики исчислялась 724 млн руб. [10. S. 1]. 
Похожие проблемы (правда, без своевольного нарушения международных двусторонних соглашений) возникли и в чехословацко-советских отношениях в конце 1980-х гг. В 1986-1990 гг. действовал двусторонний Торговый договор, в котором определялись объемы экспорта и импорта. Однако начиная с 1987 г. вследствие продолжавшегося снижения цен на нефть ${ }^{1}$ возникло положительное сальдо торгового баланса для Чехословакии. На практике это означало, что в связи с падением цен на нефть Чехословакия экспортировала в СССР товары на бо́льшую сумму, чем импортировала. Причем объем и количество товаров в этой двусторонней корзине оставались прежними.

Эту проблему можно было решить тремя способами. Во-первых, СССР мог отказаться от части чехословацких товаров. Безусловно, это вызвало бы серьезные экономические проблемы в самой Чехословакии. В этом случае произошло бы «нежелательное и существенное сокращение советской стороной чехословацкого экспорта машиностроения и оборудования». Чехословацкий экспорт был «территориально заменяем только в минимальной степени», так как эти товары были неконкурентоспособны на европейском рынке. Необходимо также учитывать и то обстоятельство, что советский рынок нуждался в этих товарах, и, таким образом, СССР должен был их закупить у какойнибудь другой страны. Для того чтобы урегулировать возникшую ситуацию, Советский Союз попытался в 1989-1990 гг. снижать импорт из Чехословакии в области машиностроения, так как к концу 1990 г. мог возникнуть дефицит торгового баланса на уровне 5 млрд переводных рублей [11]. В этой связи хотелось бы подчеркнуть, что СССР не собирался нарушать свои договорные обязательства, как это сделала Восточная Германия.

Во-вторых, существовала возможность повышения экспорта СССР в Чехословакию. Однако в связи с состоянием экспортных фондов в советской экономике, увеличение физических объемов советских поставок в ЧССР стало невозможным даже в области обрабатывающей промышленности [11].

Оба эти варианта не устраивали ни одну из сторон. Решение проблемы виделось в выделении кредита правительством ЧССР для погашения отрицательного сальдо торгового баланса Советского Союза, т.е. на закупку чехословацких товаров, поставляемых в СССР. Такой подход в итоге не привел к катастрофическим последствиям ни для одной из этих стран. По сути дела, Чехословакия, таким образом, поддержала свое производство, свой экспорт в СССР. Такую же поддержку оказали, к примеру, и США в 1993 г. своему сельскому хозяйству. Тогда была выделена помощь для РФ в размере 1,6 млрд долл. США, из которой 700 млн долл. ушло на закупку Россией американского зерна [12. S. 2]. Следовательно, такая политика чехословацкого правительства была не единичным случаем в мировой практике.
Впервые вопрос о задолженности обсуждался на встрече председателя Совета министров СССР Николая Рыжкова с председателем правительства ЧССР Ладиславом Адамецом в середине февраля 1989 г. Советский политик попросил правительство ЧССР предоставить кредит в размере до 2 млрд руб. со сроком погашения после 1995 г.; Л. Адамец согласился с данным предложением [13. S. 4].

После этих переговоров наступило время подготовки текста Соглашения о предоставлении Чехословакией кредита Советскому Союзу, которое было подписано 10 ноября 1989 г. В «Пояснительной записке» Министерства внешней торговли ЧССР к данному договору объясняется к чему в итоге пришли эксперты обеих сторон. Во-первых, процентная ставка по кредиту составила 5\% годовых, а не 5,5\%, как в случае с чехословацкой задолженностью перед бывшей ГДР. Этот кредит был предоставлен в трех частях до конца 1990 г. в размере, соответствующем реально возникшему сальдо, но не более чем 2 млрд руб. Эти позиции полностью отвечали интересам СССР. Во-вторых, погашение этого кредита должно было начаться с 1996 г. советскими товарами, соответствующими структуре экспорта СССР в ЧССР, в том числе и топливно-энергетическим сырьем, на чем настаивала чехословацкая сторона. Последний транш по данному договору планировался на 2000 г. При этом, в случае возникновения положительного сальдо СССР в торговом обороте с ЧССР, кредит мог быть погашен и досрочно. В-третьих, стороны договорились и по поводу валютной клаузулы. Имелась в виду фиксация переводного рубля к корзине свободно конвертируемых валют. Она устанавливалась по методике Международного банка по экономическому сотрудничеству (МБЭС). Модификация размера кредита могла быть проведена в случае изменения установленного МБЭС уровня переводного рубля на $\pm 5 \%$ по отношению к его основной стоимости к моменту подписания договора. С точки зрения сотрудников Министерства внешней торговли ЧССР, важность этой клаузулы заключалась в том, что чехословацкая сторона получила гарантию погашения задолженности в полном ее размере, в независимости от изменения курса переводного рубля [11].

В «Пояснительной записке» Отдела по международному разделению труда и внешним экономическим отношениям Аппарата правительства ЧССР было сделано следующее заключение: «Проект договора, обсужденный с советской стороной, содержит условия, которые можно считать приемлемыми для чехословацкой стороны». Важным для Чехословакии было и согласованное экспертами «содержание статьи 3 проекта договора о структуре поставок из СССР в ЧССР, которыми начиная с 1996 г. будет погашаться данный чехословацкий правительственный кредит, как и проценты по нему» [Там же].

Таким образом, можно сделать заключение, что этот кредит, как и причина его возникновения, имели, 
во-первых, объективные предпосылки и, во-вторых, эти вопросы решались в соответствии с интересами обеих стран, не ставя одну из них в заведомо проигрышное положение.

В начале 1990-х гг. ситуация начала усугубляться. Во-первых, СССР (а затем РФ) на выплатил проценты по кредиту в соответствии с данным договором. За 1990-1991 гг. они составляли приблизительно 700 млн долл. США, а за 1992 г. - около 800 млн долл. К тому же за экспорт чехословацких товаров в РФ в 1992 г. на сумму примерно 400 млн долл. Россией было выплачено всего лишь 26 млн долл. На момент начала второй четверти 1993 г. задолженность бывшего СССР перед бывшей ЧСФР составляла 5,57 млрд долл. [14. S. 1].

Особенно подчеркнем тот факт, что Чехословакия стала страной, самые существенные долговые обязательства по отношению к которой имел бывший СССР: на одного жителя ЧСФР приходилось 333 долл. США советской задолженности. Поэтому уже в начале 1993 г. Словакия (как, впрочем, и Чешская Республика) стремилась поставить вопрос о выплате части долга перед Россией как правопреемницей СССР.

В конце марта 1993 г. состоялся визит в Москву словацкой правительственной делегации во главе со словацким премьер-министром Владимиром Мечьяром. На переговорах министра финансов СР Ю. Тота с заместителем министра финансов РФ А. Головатым обсуждались вопросы, связанные с советской задолженностью. Последний подчеркнул, что споры вызывает не сам долг, достигающий уровня 2,2 млрд долл. США, а приемлемое для обеих сторон решение проблематики задолженности в переводных рублях. Речь шла об аккредитивах, капитальном строительстве, поставках товаров в 1991 г. Третьим аспектом являлись обычные операции за 1992 г. Поставки товаров в РФ достигли уровня 160 млн долл. А. Головатый сообщил своему собеседнику, что российская сторона изучает размер участия государства и коммерческих структур в этих операциях.

Проблемным для России был и пересчет переводного рубля к американскому доллару. Она не соглашалась с позицией других стран (Болгария, Германия, Польша, Словакия), в соответствии с которой один переводной рубль соответствовал одному доллару США. А. Головатый высказался за терпеливый поиск компромиссного решения.

В свою очередь Ю. Тот подчеркнул, что словацкая сторона может предоставить документ, подписанный ранее в рамках СЭВ, в котором утвержден курс переводного рубля к американскому доллару на уровне 1 к 1. При этом словацкий министр высказался в пользу быстрого решения данной проблемы. Ю. Тот также проинформировал своего собеседника о том, что в соответствии с законами бывшей ЧСФР чехословацкий долг делится на две части 2 к 1 между ЧР и СР, таким образом, Словакии причитается одна треть российских долговых обязательств.
На данных переговорах обсуждался и другой существенный вопрос: форма выплаты задолженности. Ю. Тот предложил три направления в урегулировании возникшей ситуации. Прежде всего, речь шла о снижении долговых обязательств поставками российских товаров. Во-вторых, допускалась капитализация задолженности, т.е. приобретение словацкими предприятиями акций российских приватизируемых заводов в счет частичного погашения долга. Осуществлению этой формы препятствовал тот факт, что на момент переговоров не был подписан сторонами договор о защите и поощрении капиталовложений, без которого реализовать данный вариант было практически невозможно. Только подписание такого документа, по словам словацкого министра, позволило бы словацким предпринимателям участвовать в российской нефтегазовой промышленности и других областях. Словацкая сторона желала, чтобы это соглашение, как и договор о запрещении двойного налогообложения, были подписаны не позднее конца июня 1993 г.

Третьим, и самым существенным, направлением в данной области были поставки специальной техники производства российского военно-промышленного комплекса. В итоге она и стала основой погашения российской задолженности перед Словацкой Республикой. Ее представители в ходе переговоров передали список интересующей их российской спецтехники [15. S. 2].

В ходе визита правительственной делегации Словакии в РФ в марте 1993 г. обсуждались вопросы, связанные с данной областью сотрудничества, и на встречах премьер-министра СР В. Мечьяра с его российским коллегой Виктором Черномырдиным и президентом РФ Борисом Ельциным [Ibid.]. В итоге задолженность и пути ее решения были включены в основной документ «Меморандум по вопросам российско-словацкого торгово-экономического сотрудничества в 1993 году», подписанный премьер-министрами двух стран.

В нем на первый план выходит решение вопроса о неоплаченных поставках из Словакии в 1991 г. на сумму около 160 млн долл. США. Именно эту позицию российской задолженности было решено ликвидировать в первую очередь. Причем для этого российская сторона предложила поставки военной техники, с чем словацкие представители согласились. В документе затронуты и другие перспективные направления по данному вопросу. В частности, договорились о разработке двумя министерствами финансов режима «постепенного урегулирования задолженности в финансовой и имущественной областях при использовании возможностей капитализации в процессе приватизации в Российской Федерации» [16. S. 3-4].

По поводу данного направления заметим два существенных факта. Во-первых, использование капитализации было оправдано, так как Россия отказалась поставлять нефть и газ, а именно такие поставки соответствовали тексту соглашения. Несмотря на это нарушение, по объективным причинам Словакия не настаива- 
ла на буквальном его выполнении. Словацкие эксперты понимали, что нефть и газ были основной статьей тогдашнего российского государственного бюджета. И жесткое исполнение договора могло бы иметь серьезные последствия для самой России. Ввиду этого российские представители согласились на словацкое предложение о капитализации задолженности. Важно подчеркнуть, что в приватизации уже участвовали иностранные компании, и, таким образом, словацкие предприниматели наряду с зарубежными субъектами получили бы в свои руки акции российских предприятий.

Во-вторых, обращает на себя внимание тот факт, что речь шла о приобретении всего лишь части акций определенных заводов с целью создания совместных предприятий. Такое сотрудничество в рыночной экономике характеризуется словацкими экономистами как самое перспективное и весьма часто встречающееся в новых условиях. В социалистической же экономике так называемая кооперация стала одной из основ и в рамках СЭВ, и в области двусторонних чехословацкосоветских экономических отношений. Не менее существенно, что имелось в виду приобретение акций российских предприятий, работавших в нефтяной и газовой промышленности, а это соответствовало чехословацко-советскому сотрудничеству 1980-х гг. Таким образом, как саму задолженность, так и пути ее погашения можно признать взаимовыгодными для обеих стран.

После этих переговоров наступил черед проведения в жизнь достигнутых договоренностей. В середине 1993 г. были созданы в обеих странах рабочие группы по решению проблем погашения задолженности. Премьер-министры двух стран на следующей встрече в Москве 23 августа 1993 г. договорились о том, что министры финансов разработают и предложат им проект, содержащий все реальные способы решения этого вопроса, включая поставки оборудования, сырья и капитализацию [17. S. 2]. Затем на первом заседании Межправительственной комиссии (МПК) по торговоэкономи-ческому и научно-техническому сотрудничеству между РФ и СР в конце ноября 1993 г. «в целях ускорения решения проблемы урегулирования задолженности бывшего СССР и Российской Федерации перед Словацкой Республикой» было принято решение заключить соглашение [18. Л. 3].

В начале 1994 г. проходили встречи словацких и российских экспертов, которые продолжались вплоть до подписания Соглашения между правительствами СР и РФ об урегулировании задолженности бывшего СССР и РФ перед Словацкой Республикой (Соглашение об урегулировании задолженности). В ходе этих переговоров стороны постепенно сближали свои позиции по отдельным направлениям погашения задолженности. Их было пять: во-первых, кредит 1989 г. (666,6 млн долл. США), во-вторых, проценты по нему за период 1990-1993 гг. (115,3 млн долл.), в-третьих, сальдо взаимных расчетов в переводных рублях (766,5 млн долл.), в-четвертых, сальдо расчетов по платежным соглашениям ЧСФРСССР (58,3 млн долл.) и, в-пятых, неоплаченные инкассовые поручения Чехословацкого торгового банка за поставки чехословацких товаров в СССР (сумма была определена в конце июня 1994 г. для всей Чехословакии - 385 млн долл.) [19. S. 1].

В итоге во второй половине июня 1994 г. сторонам удалось достигнуть компромисса практически по всем вышеперечисленным пунктам. После этого соглашение было одобрено и принято Постановлением правительства СР № 626 от 22 июня 1994 г.

Некоторые вопросы, по которым в мае-июне 1994 г. наблюдались расхождения, остались открытыми. Так, например, разногласия остались по поводу конкретной статьи, по которой долг должен быть ликвидирован поставками российского имущества специального назначения (специмущество). По представлениям российских экспертов, они должны были осуществляться в счет уплаты процентов за 1994-1995 гг. Словацкая сторона считала, что данный подход может вылиться в определенную нагрузку на государственный бюджет $\mathrm{CP}$, так как проценты могли не начисляться и, таким образом, возникла бы «парадоксальная ситуация, когда Словакия при задолженности, не погашенной российской стороной, станет ее должником». Было предложено решить этот вопрос списанием из других позиций (правительственный кредит или сальдо платежного баланса) [20. S. 1].

Однако заметим, что эти расхождения не привели к серьезным отрицательным последствиям, так как сами сотрудники Министерства финансов Словакии предложили правительству утвердить и подписать данный документ. Они предполагали, что «постепенное проведение в жизнь данного соглашения создаст пространство для приемлемого решения по реструктуризации задолженности» [19. S. 1]. Это предположение словацких экспертов оказалось верным.

Соглашение было подписано вице-премьерами правительств двух стран - Бригиттой Шмёгнеровой и Юрием Яровым на следующий же день после его принятия на заседании словацкого правительства, 23 июня 1994 г. [21. Л. 8].

На московском заседании МПК в конце июня продолжилось обсуждение данной сферы двухсторонних отношений. В частности, были затронуты вопросы по капитализации задолженности и поставкам военной техники. Что касается последней, то уже тогда был найден компромисс по сближению позиций двух сторон. В ходе дискуссии «стороны договорились о том, что поставки специмущества в соответствии с потребностями Армии Словацкой Республики будут осуществляться в счет уменьшения сальдо платежного баланса 1990 года с возможностью погашения начисляемых процентов» [Там же. Л. 11]. Это означало, что часть военной техники могла поставляться Россией в счет процентной ставки, а другая часть - путем сокращения сальдо платежного баланса. Таким образом, за- 
ключение данного соглашения создало условия для дальнейшего решения спорных вопросов.

Сегодня можно выделить два основных направления в данном процессе. В первую очередь словацкими дипломатами и экспертами ежегодно на переговорах с российской стороной ставился вопрос о включении в проекты российского бюджета финансовых средств для погашения задолженности. Впервые он обсуждался словацкими дипломатами с представителями Министерства экономики РФ В.Д. Тепленичевым и А.С. Гинзбургом в конце июля 1994 г. Российские эксперты акцентировали внимание на срочности решения этой проблемы в 1994 г., так как уже в сентябре предполагалось рассмотреть государственный бюджет РФ на 1995 г. Не позднее этого срока Министерству экономики РФ в сотрудничестве с российском Минфином следовало зарезервировать надлежащую сумму для поставок сырья в счет снижения российских долговых обязательств в бюджете РФ. Речь шла о так называемом рублевом покрытии поставок товаров, сырья и специмущества. Эти финансовые средства, выделенные из бюджета РФ, направлялись на российские предприятия для выкупа выпускаемой заводами продукции для ее поставки в Словакию [22. S. 2]. Таким образом, словацкая сторона должна была заблаговременно обеспечить включение задолженности в проекты российских бюджетов.

Отметим, что не всегда все шло столь гладко, как бы это хотелось словацким экспертам. Так, например, 6 сентября 1996 г. представители Министерства внешних экономических связей РФ подтвердили словацким дипломатам, что в первую редакцию государственного бюджета РФ на 1997 г. Минфин не включил средства на финансирование проектов по уменьшению задолженности, нереализованных в 1996 г. и даже на весь 1997 г. Это произошло, по данным российских представителей, в связи с тем, что между министерствами финансов двух стран данные вопросы не были окончательно обсуждены [23. S. 1]. Словацкий посол в Москве Роман Палдан обсудил эти проблемы с вицепремьером СР С. Козликом в Братиславе 9 сентября 1996 г. 20 сентября было передано письмо словацкого вице-премьера его российскому коллеге А. Лившицу. В нем содержалась просьба включить российскую задолженность перед Словакией в российский бюджет на 1997 г. [24. S. 1]. В итоге словацкая сторона добилась положительного результата.

Несмотря на определенные трудности, Словакия добивалась заметного успеха. Если применительно к концу апреля 1994 г. погашение задолженности РФ перед Словацкой Республикой находилось приблизительно на уровне урегулирования данного вопроса по отношению к Венгрии и Чешской Республике, то в 1995 г. ситуация была иной. Можно согласиться с министром финансов РФ В. Пансковым, который констатировал, что «Словакия - одна из немногих стран, которой Россия начала в сравнительно больших объемах выплачивать долги» [25]. А в начале сентября 1996 г. в ходе встречи с Р. Палданом сотрудница российского Минфина Елена Большакова «особенно подчеркнула, что после визита в Братиславу заместитель министра финансов РФ Михаил Касьянов предрасположен оценивать словацкие требования более снисходительно». Однако существовали и иные подходы, прежде всего на уровне среднего управленческого звена Минфина РФ. По мнению того же эксперта, «существуют люди, которые подчеркивают, что российская задолженность Словакии, учитывая ее размер, ликвидируется слишком быстро и щедро» [23. S. 1].

Второе направление заключалось в проведении переговоров и подписании протоколов по конкретным проектам в области погашения задолженности: специмущество, капитализация, поставка сырья и товаров и др.

Первые переговоры на высшем уровне после подписания Соглашения об урегулировании задолженности состоялись в начале 1995 г. На встрече министра финансов и вице-премьера правительства СР С. Козлика с главой российского Минфина были обсуждены поставки «нестратегического сырья» (сырье и энергоресурсы, за исключением нефти и газа), а также товары и специмущество. Вице-премьер правительства РФ Ю. Яров 12 января посоветовал своему словацкому коллеге обсудить «вопрос о перспективах создания совместной рабочей группы в Москве» в ходе переговоров с первым заместителем председателя правительства РФ А. Чубайсом. Ее члены занимались бы капитализацией «части российской задолженности в акции российских приватизируемых предприятий, которые имеют кооперационные связи со словацкими экономическими субъектами». Этот вопрос был обсужден С. Козликом на следующий день на встречах с А. Чубайсом и министром экономики РФ Е. Ясиным. С последним словацкий вице-премьер рассмотрел и другие формы урегулирования этого вопроса (поставка товаров, нестратегического сырья, военной техники), по которым получил поддержку [25].

В ходе третьего заседания МПК 9-11 февраля 1995 г. стороны обсудили как механизм, так и технические вопросы, связанные с погашением российских долговых обязательств. Словацкие эксперты настаивали на капитализации, ориентированной как на незаконченное строительство заводов, так и на приобретение акций приватизируемых предприятий. Российские представители предложили создать рабочую группу, которая займется подготовкой и реализацией конкретных проектов по данному вопросу. На этом заседании также обсуждались и поставки военной техники в Словакию [26. S. 3-4].

28 сентября 1995 г. в Москве состоялись переговоры уполномоченных делегаций сторон по вопросу реализации Соглашения об урегулировании задолженности. В ходе встречи был подписан Протокол, который решал три основные на тот момент задачи. Во-первых, была достигнута договоренность о продлении сроков погашения задолженности по неоплаченным инкассо- 
вым поручениям до конца 1996 г. Причем погашение этого вида задолженности осуществлялось поставками товаров по взаимосогласованной номенклатуре.

Во-вторых, констатировалось, что в 1995-1996 гг. будет осуществлено погашение части задолженности поставками спецтехники в соответствии с Протоколом № 2 от 23 мая 1994 г. (90 млн долл. США) и Протоколом № 3 от 18 августа 1995 г. (202 млн долл.). При этом бо́льшую часть этих поставок в соответствии с протоколом следовало осуществить в 1995 г.

В-третьих, «по обоюдному согласию» было принято решение о том, что погашение задолженности будет осуществлено в товарной форме, а не в свободно конвертируемой валюте. Имелись в виду «суммы, предусмотренные к погашению в соответствии со ст. 3 п. 1 (кредит ЧССР правительству СССР по договору от 10 ноября 1989 г. - В.Н.) и проценты в соответствии со ст. 3 п. 2 абз. 2 (начисляемые проценты по сальдо взаимных расчетов в переводных рублях. - B.H.) указанного Соглашения» [27. S. 1-3].

Отметим, что российская сторона отказалась от этой «валютной формы» снижения долга и по отношению к другим странам. Так, например, в начале февраля 1997 г. сотрудник Министерства внешних экономических связей РФ А. Мазилов сообщил словацким дипломатам, что чешская сторона на заседании чешско-российской межправительственной комиссии «в качестве весьма серьезной проблемы поставила <...> вопрос о погашении задолженности Чешской Республике российской стороной целиком или частично финансовыми средствами», т.е. в свободно конвертируемой валюте. Российская сторона не согласилась с этим требованием [28. S. 2]. Напомним, что позиция чехов противоречила тексту договора от 10 ноября 1989 г. применительно, по крайней мере, к задолженности бывшего СССР перед Чешской Республикой. К тому же такой механизм противоречил как обязательствам России по отношению к Международному валютному фонду, так и принципам Парижского клуба. В начале 1996 г. словацким дипломатам было заявлено, что снижение долговой нагрузки будет осуществляться «поставками товаров и только в исключительных случаях <..> переводом финансовых средств» [29. S. 2]. Таким образом, словацкой стороной уже в середине 1995 г. был достигнут компромисс с Российской Федерацией о форме выплаты задолженности.

На четвертом заседании МПК 26-27 октября 1995 г. обсуждались различные направления в этой области (поставки специального имущества, поставки товаров, гражданских самолетов и судов, капитализация, погашение задолженности словацким предприятиям). Был назначен состав смешанной рабочей группы по капитализации долговых обязательств. Также в сентябре было заявлено о согласии использовать «товарную форму» снижения российского долга [30. S. 2-3].

В конце января 1996 г. в ходе встречи заместителя министра финансов СР Татьяны Шилханковой с заместителем министра финансов РФ Михаилом Касьяновым стороны констатировали, что в рамках соглашения об урегу- лировании задолженности разработано несколько проектов по погашению как государственного долга (например, поставки атомного топлива на сумму 70 млн долл. США), так и задолженности предприятий (в частности, поставки угля или химической продукции).

На этих переговорах, однако, возникла другая проблема. Оказалось, что у сторон возникли серьезные расхождения в информации по поводу проведения в жизнь конкретных проектов, направленных на осуществление Соглашения об урегулировании задолженности. Это можно объяснить кадровыми перестановками в российском Минфине. В связи с этим была достигнута договоренность провести «обстоятельную инвентаризацию осуществления выполнения межправительственного соглашения и установить приоритеты на 1996 и последующие годы» [29. S. 2]. Эта проблема, однако, была решена уже в первой трети 1996 г.

В ходе следующей встречи М. Касьянова с Т. Шилханковой 3 апреля 1996 г. был подписан Протокол между Министерством финансов СР и российским Минфином о ходе выполнения Соглашения об урегулировании задолженности. В данном документе более обстоятельно, чем в Протоколе от 29 сентября 1995 г., были зафиксированы договоренности двух стран по трем основным направлениям. Во-первых, было подтверждено, что погашение долга перед словацкими предприятиями будет осуществлено поставками российских товаров до конца 1996 г., что соответствовало Протоколу от 29 сентября 1995 г. При этом словацкая сторона передала список словацких компаний, которые выступали реципиентами данной российской продукции. Речь шла о трех фирмах: «Хирана Экспорт-Импорт» (Пьештяны), «Каушн» (Братислава) и «Ремарк» (Братислава).

Во-вторых, по отношению к государственной задолженности словацкие представители пожелали уже в 1996 г. получить на сумму около 400 млн долл. США самолет ТУ-154 М и его модификации, а также самолеты Як 42-Д. Словацкие эксперты проявили заинтересованность в российском оборудовании (для Словацких железных дорог, для телепорта в Братиславе, а также для строительства циклотронного центра). Российская сторона также согласилась на поставку в Словакию специального стального листа для резервуаров нефти и военной продукции Московского авиационного производственного объединения («МАПО»).

Российские представители заявили, что рассмотрят данную просьбу с учетом ее возможностей в текущем финансовом году. Словацкие участники переговоров просили ускорить поставку военно-технической продукции в размере 90 млн долл. США (в соответствии с Протоколом № 2 от 23 марта 1994 г.), что и было обещано. Также было достигнуто решение по поставкам энергоресурсов в счет снижения долга. Словацкая Республика в 1997-1999 гг. получила ядерное топливо для атомной электростанции «Моховце» на сумму 70 млн долл.

Третьим аспектом, который обсуждался в ходе этих переговоров, были технические вопросы, связанные с 
урегулированием задолженности. Во-первых, стала очевидной необходимость усиления контроля со стороны министерств финансов двух стран за процедурой списания долговых обязательств, урегулирование которых происходило путем поставок российских товаров. Во-вторых, уполномоченным банкам следовало предпринять необходимые меры для ликвидации возникших технических проблем, связанных с учетом осуществленных платежей в счет задолженности путем поставок российских товаров. Речь шла главным образом о поставках производства «МАПО». В-третьих, словацкая сторона проинформировала о решении правительства предоставить полномочия словацкороссийскому банку «Девин» на проведение организационной работы, связанной со снижением российского долга перед Словакией поставками товаров [31. S. 1-3].
Таким образом, наряду с существованием некоторых проблем, например неполучением спецтехники в 1995 г. по протоколу № 2, подписанного еще в марте 1994 г., ситуация постепенно улучшалась ${ }^{2}$. Переговоры и подписание протоколов, направленных на выработку динамики урегулирования задолженности, продолжились и в более позднее время при правительстве Микулаша Дзуринды (1998-2006 гг.). Оно, по сути дела, использовало наработки предыдущего правительства в данной области. Даже инструментарий и система переговоров остались прежними. Этот факт красноречивее всего свидетельствует о профессиональной, качественной политике по погашению российских долговых обязательств правительством В. Мечьяра, политике, благодаря которой несомненно проводились в жизнь национальные и экономические интересы Словакии.

\section{ПРИМЕЧАНИЯ}

1 Цена нефти в 1989 г. была на уровне всего лишь 70\% от уровня цен 1986 г. [11].

2 Это происходило благодаря разработке и принятию протоколов в ходе двусторонних встреч. Иногда они не выполнялись целиком, о чем словацкая сторона постоянно напоминала российским экспертам. Случалось даже, что российский Минфин в свою защиту использовал тот аргумент, который противоречил подписанному Россией тексту Протокола от 29 сентября 1995 г. [32. S. 1]

\section{ЛИТЕРАТУРА}

1. Duleba A., Hirman K. Rusko na konci Jel’cinovej éry. Zahraničná a vnútorná politika, rozširovanie NATO a záujmy Slovenska. Bratislava : Inštitút pre verejné otázky, 1999. $321 \mathrm{~s}$.

2. Duleba A. Slepý pragmatizmus slovenskej východnej politiky: Aktuálna agenda slovensko-ruských bilaterálnych vzt’ahov. Bratislava : Výskumné centrum Slovenskej spoločnosti pre zahraničnú politiku, 1996. $58 \mathrm{~s}$.

3. Duleba A. Slovensko-ruská spolupráca vo vojenskej a vojensko-priemyselnej oblasti alebo Kde sa končí obchod a začína politika // Mezinárodní vztahy. Praha, 1998. Č. 1. S. 38-55.

4. Dmitrenko A. Slovensko má šancu získat' od Ruska splatenie dlhov // Národná obroda. 19 januára 1995.

5. Вышеградская Европа: Откуда и куда? Два десятилетия по пути реформ в Венгрии, Польше, Словакии и Чехии / под ред. Л.Н. Шишелиной. М. : Весь мир, 2010. 563 с.

6. Ferenčíkova S. Operácie v medzinárodnom obchode // Medzinárodné podnikanie. Bratislava : Sprint, 1995. $486 \mathrm{~s}$.

7. Vel'ká ekonomická encyklopédia. Bratislava : Sprint, 1996. $614 \mathrm{~s}$.

8. SNA (Словацкий национальный архив). F. ÚV SR 1993-1996, šk. 173, č.m. 0873/96, tajné. Predkladacia správa. Správa o priebehu a výsledkoch rokovaní k problematike riešenia pasívneho salda platobnej bilancie bývalej ČSFR voči bývalej NDR, ktoré sa konali 6 . a 7 . mája 1996.

9. SNA. F. ÚV SSR/SR 1981-1992, Zasadania vlády ČSFR, šk. 550, č. j. 7182/90, Důvodová zpráva. Charakteristika vývoje zahraničně obchodních vztahů v letech 1986-1990 a návrh zásad spolupráce v obchodě po roce 1990 s NDR.

10. SNA. F. ÚV SSR/SR 1981-1992, Zasadania vlády ČSFR, šk. 553, č. j. 7402/90-15, Důvodová zpráva. Výsledky jednání mezi ministrem zahraničního obchodu ČSFR a ministrem hospodářství NDR k problematice negativního vývoje obchodní bilance a platební bilance v roce 1990 mezi ČSFR a NDR.

11. SNA, f. ÚV SSR/SR 1981-1992, Zasadania vlády ČSSR, šk. 537, č.j. 0670/89-taj. Příloha I. Sjednání dohody s vládou SSSR o poskytnutí úvěru vládě SSSR.

12. DA MZV SR (Дипломатический архив Министерства иностранных дел Словацкой Республики). F. ZÚ Washington, kr. 24, fasc. 253-100, с̌.m. $1579 / 93$.

13. SNA. F. ÚV SSR/SR 1981-1992, Zasadania vlády ČSSR, šk. 525, č.j. 0171/89-taj., Př́loha II. Průběh a výsledky oficiální přátelské návštěvy předsedy vlády ČSSR v SSSR.

14. DA MZV SR. F. ZÚ Moskva, kr. 83, fasc. 210-107, Informácia o súčasnom stave finančných pohl’adávok voči býv. ZSSR, s. 1.

15. SNA. F. ÚV SR 1993-1996, šk. 16, č.m. 1798/93, Príloha I. E. Informácia o priebehu a výsledkoch oficiálnej návštevy delegácie vlády SR vedenej jej predsedom V. Mečiarom v RF v dňoch 24. a 25. marca 1993.

16. SNA. F. ÚV SR 1993-1996, šk. 14, fasc. Rôzne, Memorandum o otázkach slovensko-ruskej obchodno-ekonomickej spolupráce v roku 1993 z výsledkov rozhovorov uskutočnených dňa 25. marca 1993 v Moskve medzi predsedom vlády SR V. Mečiarom a predsedom Rady ministrov-vlády RF V. Černomyrdinom.

17. DA MZV SR. F. ZÚ Moskva, kr. 80, fasc. 253-100, č.m. 2836/93/SVV.

18. АВП РФ. Ф. 888. ОП. 1. Пап. 1. Д. 5.

19. SNA. F. ÚV SR 1993-1996, šk. 76, č.m. 2865/94, Predkladacia správa. Návrh Dohody medzi vládou SR a vládou RF o riešení zadíženosti bývalého ZSSR a Ruskej federácie voči SR.

20. DA MZV SR F. ZÚ Moskva, kr. 84, fasc. 256-100, Záznam z rokovania.

21. АВП РФ. Ф. 888. Оп. 2. Пап. 2. Д. 6.

22. DA MZV SR. F. ZÚ Moskva, kr. 84, fasc. 256-100, č.m. 21479/94/SVV.

23. DA MZV SR. F. ZÚ Moskva, kr. 92, fasc. 256-100, č.m. 1.002/96-EOU-042.

24. DA MZV SR. F. ZÚ Moskva, kr. 93, fasc. 256-100, č.m. 4851/96-PÚ.

25. DA MZV SR. F. ZÚ Moskva, kr. 89, fasc. 210-100, Materiály z pracovnej návštevy podpredsedu vlády Sergeja Kozlíka v RF v dňoch 12-14 januára 1995.

26. SNA. F. ÚV SR 1993-1996, šk. 111, č.m. 990/95. Protokol z 3. zasadnutia Medzivládnej komisie pre obchodno-hospodársku a vedecko-technickú spoluprácu medzi SR a RF. 
27. DA MZV SR. F. ZÚ Moskva, kr. 86, fasc. 256-100, Протокол

28. DA MZV SR. F. ZÚ Moskva, kr. 95, fasc. 256-100, č.m. 1510/97-EOU14.006.

29. DA MZV SR. F. ZÚ Moskva, kr. 92, fasc. 256-100, č.m. 1.002/96-EOU-04.

30. SNA. F. ÚV SR 1993-1996, šk. 142, č.m. 4138/95. Protokol zo 4. zasadnutia Medzivládnej komisie pre obchodno-hospodársku, vedecko-technickú a kultúrnu spoluprácu medzi SR a RF.

31. DA MZV SR. F. ZÚ Moskva, kr. 92, fasc. 256-100, Протокол между Министерством финансов СР и Министерством финансов РФ о ходе выполнения межправительственного Соглашения от 26.4 .94 об урегулировании задолженности бывшего СССР и РФ перед СР.

32. DA MZV SR. F. ZÚ Moskva, kr. 92, fasc. 256-100, č.m. 1.002/96-EOU-15.

Victor Nikitin V. Institute for Slavic Studies of Russian Academy of Science (Moscow, Russia). E-mail: nikitin.viktor.1979@gmail.com THE RISE OF SOVIET DEBT AND WAYS OF ITS SETTLEMENT IN THE SLOVAK-RUSSIAN RELATIONS IN THE 1990-S

Keywords: repayment of Soviet debts; Slovak-Russian relations; foreign policy; economic relations; diplomacy.

The author in this article analyzes the role of Soviet debt in Slovak-Russian relations in the 1990s. This issue has already been raised in historiography, but only on the basis of journalism. The available archive base (diplomatic reports and documents of the Czechoslovak and Slovak governments) provides an opportunity to take a more qualitative look at this question. Therefore the author for the first time in the world historiography may show the causes of origin of soviet debt, the dynamics of its settlement, as well as its role in the Russian vector of Slovak foreign policy.

At the beginning of article are described the reasons for the appearance of Soviet debt (fall in oil prices), which led to the appearance of a negative balance in the Soviet-Czechoslovak trade, and are analyzed possible ways of solving this problem. The author comes to a conclusion that the Czechoslovak and Soviet governments, having concluded an Agreement on the Czechoslovak credit arrangement for the USSR on November 10, 1989, selected the path that would suit interests of both states.

After the velvet revolution, Soviet debt rose to $\$ 5$ billion. Therefore, the issue of its settlement was raised during the first visit of the Slovak government delegation in Moscow in March 1993. During the negotiations, two main directions in this field were discussed: a size of the debt and a form of its payment. The amount of debt owed by Slovakia after the dissolution of Czech and Slovak Federative Republic was $\$ 1.7$ billion. It was paid for by the supply of goods, military-industrial production, energy resources, shares of Russian privatized enterprises. Later, in the first half of 1994, Slovakia signed an agreement with Russia on settlement the debts of the former USSR and the Russian Federation to Slovakia, which outlined the main mechanisms for Russia's repayment of debt obligations.

To implement these mechanisms, frequent consultations were held at the level of the ministries of the two countries. The author identifies two main areas in the negotiation process. First of all, it was necessary to reserve financial resources in the Russian budget, which were allocated for the purchase of goods provided by Russia to partially repay the debt. Then, at the talks it was necessary to sign protocols on specific projects for which these funds were intended. The author concludes that during the meetings, as much as possible, the representatives of the two states defended its national and economic interests.

The article also emphasizes negative phenomena in this kind of cooperation: agreements were not always implemented, sometimes there was a serious delay, not all officials of ministries understood the importance of this sphere in Slovak-Russian relations. Despite these temporary problems, which arose at that time because of the objective prerequisites, the author focuses attention on the successful completion of this field of bilateral relation.

\section{REFERENCES}

1. Duleba, A. \& Hirman, K. (1999) Rusko na konci Jel'cinovej éry. Zahraničná a vnútorná politika, rozširovanie NATO a záujmy Slovenska [Russia at the end of the Eltsin era. Foreign and domestic policy, NATO expansion and the interests of Slovakia]. Bratislava: Inštitút pre verejné otázky.

2. Duleba, A. (1996) Slepý pragmatizmus slovenskej východnej politiky: Aktuálna agenda slovensko-ruských bilaterálnych vzt'ahov [The Blind Pragmatism of Slovak Eastern Policy: The Current Agenda of the Slovak-Russian Bilateral Relations]. Bratislava: Research Centre of the Slovak Society for Foreign Policy.

3. Duleba, A. (1998) Slovensko-ruská spolupráca vo vojenskej a vojensko-priemyselnej oblasti alebo Kde sa končí obchod a začína politika [SlovakRussian cooperation in the military and industrial area or where the trade ends and the policy begins]. Mezinárodní vztahy. 1.pp. 38-55.

4. Dmitrenko, A. (1995) Slovensko má šancu získat' od Ruska splatenie dlhov [Slovakia has the chance to obtain debt repayment from Russia]. Národná obroda. 19th January.

5. Shishelina, L.N. (ed.) (2010) Vyshegradskaya Evropa: Otkuda i kuda? Dva desyatiletiya po puti reform v Vengrii, Pol'she, Slovakii i Chekhii [The Visegrad Europe: Where and from where? Two decades on the path of reforms in Hungary, Poland, Slovakia and the Czech Republic]. Moscow: Ves' mir.

6. Ferenčíkova, S. (1995) Operácie v medzinárodnom obchode [Operations in International Trade]. In: Baláž, P. et al. Medzinárodné podnikanie [International Business]. Bratislava: Sprint, 1995. 486 s.

7. Š́bl, D. et al. (1996) Vel'ká ekonomická encyclopedia [Great Economic Encyclopedia]. Bratislava: Sprint.

8. Slovak National Archives. (1996) Predkladacia správa. Správa o priebehu a výsledkoch rokovaní k problematike riešenia pasívneho salda platobnej bilancie bývalej ČSFR voči bývalej NDR, ktoré sa konali 6. a 7. mája 1996 [Draft report. Report on the course and outcome of negotiations on the issue of solving the passive balance of the balance of payments of the former CSFR against the former GDR, held on 6 and 7 May 1996]. Fund UVV SR 1993-1996, šk. 173, č.m. 0873/96.

9. Slovak National Archives. (1990a) Důvodová zpráva. Charakteristika vývoje zahraničně obchodních vztahů v letech 1986-1990 a návrh zásad spolupráce v obchodě po roce 1990 s NDR [Explanatory Memorandum. The characteristics of the development of foreign trade relations between 19861990 and the draft principles of cooperation in the after 1990 trade with the GDR]. Fund ÚV SSR/SR 1981-1992. Meetings of the Government of the Czechoslovak Socialist Republic, No. 550, No. 7182/90.

10. Slovak National Archives. (1990b) Důvodová zpráva. Výsledky jednání mezi ministrem zahraničního obchodu ČSFR a ministrem hospodářství NDR $k$ problematice negativního vývoje obchodni bilance a platební bilance v roce 1990 mezi ČSFR a NDR [Explanatory Memorandum. The results of negotiations between the Minister of Foreign Trade of the CSFR and the Minister of Economy of the GDR on the issue of the negative development of the trade balance and the balance of payments in 1990 between the CSFR and the GDR]. Fund ÚV SSR/SR 1981-1992. Meetings of the Government of the Czechoslovak Socialist Republic, No. 553, No. 7402 / 90-15.

11. Slovak National Archives. (n.d.) Přiloha I. Sjednání dohody s vládou SSSR o poskytnutí úvěru vládě SSSR [A I. Arrangement of agreement with the Government of the USSR on granting credit to the Government of the USSR]. Fund ÚV SSR/SR 1981-1992. Meetings of the Government of the Czechoslovak Socialist Republic, File 537, ref. 0670/89-secret.

12. Diplomatic Archives Ministry of Foreign Affairs of the Slovak Republic (DA MZV SR). (n.d.) Fund ZÚ Washington. 24. Vol. 253-100. No. 1579/93.

13. Slovak National Archives. (n.d.) Přiloha II. Průběh a výsledky oficiální prátelské návštěvy předsedy vlády ČSSR v SSSR [Appendix II. The course and results of the official friendly visit of the Prime Minister of the CSSR in the USSR]. Fund UV SSR/SR 1981-1992. Meetings of the Government of the Czechoslovak Socialist Republic, 525, File 0171/89-secret. 
14. Diplomatic Archives Ministry of Foreign Affairs of the Slovak Republic. (DA MZV SR). (n.d.) Informácia o súčasnom stave finančných pohladávok voči býv. ZSSR [Information on the current state of financial claims against the former. USSR]. Fund ZÚ Moskva. 83. Vol. 210-107.

15. Slovak National Archives. (1993) Príloha I. E. Informácia o priebehu a výsledkoch oficiálnej návštevy delegácie vlády SR vedenej jej predsedom V. Mečiarom v RF v dňoch 24. a 25. marca 1993 [Annex I. E. Information on the progress and results of an official visit by a delegation of the Government of the Government led by its President V. Mečiar in RF on 24 and 25 March 1993]. Fund ÚV SR 1993-1996. 16. No. 1798/93,.

16. Slovak National Archives. (1993) Memorandum o otázkach slovensko-ruskej obchodno-ekonomickej spolupráce v roku 1993 z výsledkov rozhovorov uskutočnených dňa 25. marca 1993 v Moskve medzi predsedom vlády SR V. Mečiarom a predsedom Rady ministrov-vlády RF V. Černomyrdinom [Memorandum on Slovak-Russian trade and economic cooperation in 1993 from the results of the interviews held on March 25, 1993 in Moscow, between the Prime Minister of the Slovak Republic V. Mečiar and the Chairman of the Council of Ministers-Government RF V. Chernomyrdin]. Fund ÚV SR 1993-1996. 14. Miscellaneous.

17. Diplomatic Archives Ministry of Foreign Affairs of the Slovak Republic. (DA MZV SR). (n.d.) Fund ZÚ Moskva. 80. Vol. 253-100. No. 2836/93/SVV.

18. Archive of the Foreign Policy of the Russian Federation. (n.d.) Fund 888. List 1. File 1. Doc. 5.

19. Slovak National Archives. (1993) Predkladacia správa. Návrh Dohody medzi vládou SR a vládou RF o riešení zadlženosti bývalého ZSSR a Ruskej federácie voči SR [Draft Agreement between the Government of the Slovak Republic and the Government of the Russian Federation on Solving the Debt of the former USSR and the Russian Federation towards the Slovak Republic]. Fund ÚV SR 1993-1996. 76. No. $2865 / 94$.

20. Diplomatic Archives Ministry of Foreign Affairs of the Slovak Republic. (DA MZV SR). (n.d.) Fund ZÚ Moskva. 84. Vol. 256-100.

21. Archive of the Foreign Policy of the Russian Federation. (n.d.) Fund 888. List 2. File 2. Doc. 6.

22. Diplomatic Archives Ministry of Foreign Affairs of the Slovak Republic. (DA MZV SR). (n.d.) Fund ZÚ Moskva. 84. Vol. 256-100. No. 21479/94/SVV.

23. Diplomatic Archives Ministry of Foreign Affairs of the Slovak Republic. (DA MZV SR). (n.d.) Fund ZÚ Moskva. 84. Vol. 256-100. No. 1.002/96EOU-042.

24. Diplomatic Archives Ministry of Foreign Affairs of the Slovak Republic. (DA MZV SR). (n.d.) Fund ZÚ Moskva. 84. Vol. 256-100. No. 4851/96PÚ.

25. Diplomatic Archives Ministry of Foreign Affairs of the Slovak Republic. (DA MZV SR). (n.d.) Materiály z pracovnej návštevy podpredsedu vlády Sergeja Kozlika v RF v dňoch 12.-14. januára 1995 [Materials from a working visit by Deputy Prime Minister Sergei Kozlik in RF on January 1214, 1995]. Fund ZÚ Moskva. 89. Vol. 210-100.

26. Slovak National Archives. (n.d.) Protokol z 3. zasadnutia Medzivládnej komisie pre obchodno-hospodársku a vedecko-technickú spoluprácu medzi $S R$ a $R F$ [Protocol of the 3rd Meeting of the Intergovernmental Commission for Trade, Economic and Scientific Cooperation between the SR and RF]. Fund ÚV SR 1993-1996. 111. No. 990/95.

27. Diplomatic Archives Ministry of Foreign Affairs of the Slovak Republic. (DA MZV SR). (n.d.) Fund ZÚ Moskva. 86. Vol. 256-100.

28. Diplomatic Archives Ministry of Foreign Affairs of the Slovak Republic. (DA MZV SR). (n.d.) Fund ZÚ Moskva. 95. Vol. 256-100. No. 1510/97EOU14.006.

29. Diplomatic Archives Ministry of Foreign Affairs of the Slovak Republic. (DA MZV SR). (n.d.) Fund ZÚ Moskva. 92. Vol. 256-100. No. 1.002/96EOU-04.

30. Slovak National Archives. (n.d.) Protokol zo 4. zasadnutia Medzivládnej komisie pre obchodno-hospodársku, vedecko-technickú a kultúrnu spoluprácu medzi SR a RF [Protocol of the Fourth Session of the Intergovernmental Commission for Trade, Scientific, Technical and Cultural Cooperation between the SR and RF]. Fund ÚV SR 1993-1996. 142. 4138/95..

31. Diplomatic Archives Ministry of Foreign Affairs of the Slovak Republic. (DA MZV SR). (n.d.) Protokol mezhdu Ministerstvom finansov SR i Ministerstvom finansov RF o khode vypolneniya mezhpravitel'stvennogo Soglasheniya ot 26. 4.94 ob uregulirovanii zadolzhennosti byvshego SSSR $i$ RF pered $S R$ [Protocol between the Ministry of Finance oft he Slovak Republick and the Ministry of Finance oft he Russian Federation on the Implementation of Agreement of April 26, 1994, on the settlement of the former USSR and the Russian Federation debt before the SR]. Fund ZÚ Moskva. 92. Vol. 256-100.

32. Diplomatic Archives Ministry of Foreign Affairs of the Slovak Republic. (DA MZV SR). (n.d.) Fund ZÚ Moskva. 92. Vol. 256-100. No. 1.002/96EOU-15. 